\title{
CROSS-BORDER WATER USE PROBLEMS IN RUSSIA AND UKRAINE
}

\author{
G. Kharitonov \\ Don state technical university. Rostov-on-Don, Russian Federation \\ science-almanac@mail.ru
}

\begin{abstract}
There are objectively contradictions between the countries in the field of use and protection of the water resources of river basins belonging to their territory in the basins of Transboundary Rivers. This creates problems in interstate relations, not contributing to economically efficient and environmentally sustainable water consumption. This situation requires the search for objective criteria for assessing the situation and methods for reaching a compromise solution arranging the stakeholders. Lots depend on the economic level development of the contracting parties and diplomacy. Sometimes one state can yield some of its rights to water resources in exchange for any other economic or political benefits. For the implementation of agreements the Member States create joint commissions for the management of transboundary water bodies. Their decisions have legal force and are binding for the participants, but the agreements usually do not describe the mechanisms of impact in the event of their non-fulfillment. This is due to a considerable extent to the lack of established rules for the use of transboundary water bodies, as well as the inevitable measures of liability for their violation. It is considered that participation in international agreements on the use of transboundary water bodies is a good will of the countries.Conflict situations, related to water consumption, are dominant on the prevalence. One of the reasons for their occurrence is the unequal position of countries in relation to the areas of water formation and decrement. As a rule, the development of coordinated strategies for the use of the resources of transboundary water bodies and the resolution of their conflict situations are achieved through lengthy negotiations and consultations with experts. At the same time each party advocates first of all the interests, using all possible methods including any pressure for justification of the position. In cases where the understanding of the community of interests comes to the forefront, significant results can be achieved.For the purpose of settlement of the water relations on the cross-border rivers on October 19, 1992 in Kiev the Agreement between the Governments of Russia and Ukraine on sharing and protection of cross-border water objects which determined the basic principles of sharing of waters, coherences of water management actions implementation, the organizations of observations of a condition of a surface water was signed. The representative of Ukraine cabinet council for implementation of the agreement is the chairman of the Ukraine State water agency, the Representative of the Government of the Russian Federation - the head of Federal Agency for Water Resources of the Russian Federation; Deputy Representatives for implementation of the agreement in the basin of the river the Seversky Donets: From the Ukrainian side is the head of the Seversky-Donetsk basin water resources management, with the Russian side is the head of the Don basin water management. Regulatory documents have been developed for the implementation of the intergovernmental agreement: The order of works organization on water resources management in the Seversky Donets River basin; The program of joint quality control of water for hydrochemical and toxicological indicators; The order of interaction in emergency situations on transboundary water bodies. Despite the strained political relations between Russia and Ukraine, a comprehensive solution of environmental and resource problems in the basins of transboundary rivers, implementation of multifaceted investment projects, the development of the scientific and technical base and training of personnel should become important factors for the sustainable development of these states, and the expansion of their integration cooperation.

Key words: cross-border water consumption, intergovernmental agreements, watershed management, water supply deficit, the Seversky Donets, Relations between Russia and the Ukraine.
\end{abstract}

\section{[Харитонов Г.Б. Трансграничные проблемы водопользования России и Украины]}

В бассейнах трансграничных рек объективно существуют противоречия между странами в области использования и охраны водных ресурсов речных бассейнов, относящихся к их территории. Это создает проблемы в межгосударственных отношениях, не способствуя экономически эффективному и экологически устойчивому водопользованию. Такая ситуация требует поиска объективных критериев оценки ситуации и методов для достижения компромиссного решения, устраивающего заинтересованные стороны. Многое зависит от уровня экономического развития договаривающихся сторон и дипломатии. Иногда одно государство может уступить часть своих прав на водные ресурсы в обмен на какие-либо другие экономические или политические выгоды. Для реализации соглашений 
государствами-участниками создаются совместные комиссии по управлению трансграничными водными объектами. Их решения имеют юридическую силу и обязательны для участников, но в соглашениях обычно не прописаны механизмы воздействия в случае их невыполнения. В значительной мере это объясняется отсутствием установленных правил пользования трансграничными водными объектами, а также неотвратимых мер ответственности за их нарушение. Считается, что участие в международных соглашениях по использованию трансграничных водных объектов - добрая воля самих стран.Конфликтные ситуации, связанные с водопользованием, занимают первое место по своей распространенности. Одна из причин их возникновения - неравное положение стран по отношению к областям фрормирования и разгрузки вод. Как правило, разработка согласованных стратегий использования ресурсов трансграничных водных объектов, решение связанных с ними конфликтных ситуаций достигаются путем длительных переговоров и консультаций с экспертами. При этом каждая сторона отстаивает прежде всего свои интересы, используя для обоснования своей позиции все возможные методы, в том числе и разного рода давления. В случаях, когда на первый план выходит понимание общности интересов, удается добиться значительных результатов.С целью урегулирования водных отношений на трансграничных реках 19 октября 1992 г. в Киеве было подписано Соглашение между Правительствами России и Украины о совместном использовании и охране трансграничных водных объектов, которым определены основные принципы совместного использования вод, согласованности осуществления водохозяйственных мероприятий, организации наблюдений за состоянием поверхностных вод. Уполномоченным кабинета министров Украины по выполнению соглашения является председатель Госводагентства Украины, Уполномоченным Правительства Российской Федерации - руководитель Федерального агентства водных ресурсов РФ; заместители Уполномоченных по выполнению соглашения в бассейне р. Северский Донец: с украинской стороны - начальник СеверскоДонецкого бассейнового управления водных ресурсов, с российской - руководитель Донского бассейнового водного управления. Для реализации межправительственного соглашения разработаны регламентирующие документы: Порядок организации работ по управлению водными ресурсами бассейна реки Северский Донец; Программа совместного контроля качества вод по гидрохимическим и токсикологическим показателям; Порядок взаимодействия в чрезвычайных ситуациях на трансграничных водных объектах. Несмотря на напряженные политические отношения России и Украины, комплексное решение эколого-ресурсных проблем в бассейнах трансграничных рек, осуществление разносторонних инвестиционных проектов, развитие научно-технической базы и подготовка кадров должны стать важными фракторами устойчивого развития этих государств, расширения их интеграционного взаимодействия.

Ключевые слова: трансграничное водопользование, межправительственные соглашения, бассейновый принцип водопользования, дефицит водных ресурсов, река Северский Донец, отношения России и Украины.

Grigory B. Kharitonov - candidate of economics, associate professor. Don state technical university. Rostovon-Don, Russian Federation.

ХаритоновГригорийБорисович кандидатэкономическихнаук, доцент. Донскойгосударственныйтехническийуниверситет. г. Ростов-на-Дону, Россия.

One of the important problems in the use of transboundary waters is the determination of the proportions of the distribution of the respective resources between Russia and neighboring countries. In international practice, there are no clear unified criteria for this topic, but there are various theoretical approaches and real precedents that are fixed in specific treaties and agreements that take into account the natural parameters of transboundary water bodies, the types and intensity of water use, the nature and state of relations between states. Theoretically, the concepts differ and compete with each other: a) the absolute, unlimited sovereignty of each state over the water resources located on its territory; b) the absolute inviolability of the river flow coming from the territory of neighboring states; c) sovereignty, limited by certain factors; d) common interests and rights of states in the use of transboundary waters. The latter approach is most fully reflected in the Helsinki Rules for the Use of Waters of International Importance, published in 1966 by the International Law Association. According to the starting point of the document,whose authors reject the principle of unrestricted territorial sovereignty, each state with respect to 
the river basin of international importance has the right to objectively justified "reasonable and fair" share of the useful use of its water resources within its territory. This takes into account a set of factors related to natural conditions, socio-economic importance and efficiency of water resources use, historical traditions, alternative sources of water supply and water use technologies, etc. [1, p.116].

Now, international law in the field of water relations is based on the common interests of the states of a transboundary water body. At its use basin approach has to be applied, i.e. the water system is considered as a unit for the adjacent states at preservation of their national sovereignty. Any interaction between countries with common water resources should be peaceful and implemented on the principles of reciprocity, recognition of the integrity of the basin and the most rational use of water resources for the common good of these states. The parties are obliged to exchange relevant information, notify each other of planned measures that can cause significant damage, and to settle disputes peacefully. Neighboring countries conclude agreements in the field of water cooperation develop and implement measures aimed at the use and protection of transboundary water bodies.

Within the framework of existing agreements, in order to take into account all the specific features specific to user countries, in determining the conditions for the joint use of a water body and its protection, in addition to general principles, stakeholders are guided by other, more local ones. Water resources can be shared: on equal volumes of used water; in proportion to the watershed; respectively, the investment spent on hydrotechnical facilities and operational costs; by the amount of electricity received; on water content of the border area of the transboundary river basin; by historically formed economic conditions; according to the principle of equal specific water consumption per capita, etc. [3, c.23].

Insufficiency of water resources in the water areas of rivers affects the competitiveness of an individual State. Due to the economic interests of neighboring countries, there is a potential for conflicts due to the quality of water that comes to the downstream states. On this basis, the water deficit has a clearly expressed international character, and the consequences of a likely state struggle for it are difficult to predict.

The cross-border problem of water use directly affects the interests of Russia's national security and its bordering states, such as the Ukraine. It is connected with the fact that the borders are mainly in water-deficient regions with developed industry or agriculture. There are also negative consequences of active use of river flow for irrigation. Construction of reservoirs, dams, hydroelectric power stations and redistribution of flow; Pollution of surface and underground water resources by various wastes of industry, agriculture, domestic sewage and oil products; The reduction of the network of small rivers and the drainage of swamps, all this entails a systemic reorganization of the surrounding ecosystems and generally affects the water balance of the country [4, p.31].

The agreement between Russia and the Ukraine about the joint use and protection of transboundary water bodies was signed in Kiev on October 19, 1992. This Agreement defines the basic principles of joint use of water, the maintenance of water and water protection facilities, the implementation of restoration and conservation measures, the conservation and restoration of bioresources, the organization of observations of the state of surface waters, the regular exchange of information and forecasts for the development of floods, as well as the expected water content in the low water.

In accordance with this Agreement, both states coordinate [5, p.94]:

- implementation of water management measures and actions for protection of water objects against pollution;

- the maintenance-related works in proper technical condition of hydraulic and water protection facilities; 
- operational regimes of hydraulic structures, water releases, plans for water management and water protection measures; operational regime;

- development of schemes for the integrated use and protection of water resources, water management balances, taking into account the quantitative and qualitative characteristics of waters at the boundary section;

- implementation of joint water management and security actions as necessary;

- cooperation on the conservation of bioresources of reservoirs, conservation of the biological diversity of ecological systems.

In order to assess the quality of water and measure the level of pollution, both sides agree on a common program of observations and common analysis techniques, methods for assessing the state and measuring water quality.During the consideration of issues related to the implementation of the "Agreement", a meeting is held once a year. In the period between the meetings, the Authorized States coordinate the conduct of scientific, technical, design and construction works, together with experts, monitor, organize flood prevention measures, protect water from pollution, and organize the exchange of information and materials provided for the Agreement. As a result of the elaborated mechanism of the Agreement, the Russian and Ukrainian sides agreed on the organization of work on water resources management in the Seversky Donets Basin, carry out the program of joint analytical control of a hydrochemical condition of cross-border water objects, requirements for observance of hydrological and hydrochemical indicators in boundary alignments are established. The solution of such issues as the appointment of regimes for filling and discharging water from reservoirs during high water and summer and autumn low flows, discharge from sewage water storage facilities, indicators of water balance sheets, norms of maximum permissible discharges, issuing permits for special water use, construction of water facilities and others are carried out only after bilateral coordination, if these measures affect the interests of the neighboring state. The technological basis for coordinating decisions on the management of water resources is the automated information and advisory system of the united water management system of the Don and Seversky Donets river basins. The joint use of such a system allows increasing knowledge of the parties, to make activity of one party transparent and predicted for another. It gives the chance to coordinate efforts at development of decisions and to achieve the maximum effect at water resources management. It is especially important in extreme (low-water or high-water) and other critical situations (for example, the organization of spawning releases), as well as in accidents. So, active joint actions allowed to reduce damage from flooding of a flood plain as a result of high flood in 1994 in the basin of Don due to coordination of the regimes of filling reservoirs and cut of peak expenses of the deepest wave in the lower reaches of Don. In 1995, joint measures allowed to reduce the pollution of the rivers Sev and Donets during the accidental pollution of the watercourse as a result of the accident at the sewage treatment plants in Kharkov, prevent the deterioration of water quality in the Rostov region and ensure the stable operation of water intakes in Donetsk, Kamensk and Belaya Kalitva.

For interregional and transboundary basins it is necessary to solve the problem of interregional and interstate basin interaction. For basins of adjacent subjects, this can be achieved through the establishment of basin commissions. Transboundary rivers that connect the interests of border states have a special status. In the Belgorod region, there are 14 such rivers, the largest of which are the Seversky Donets, the Seym, the Psel, and the Aidar. The waters of the international river should be used

by one party so as not to significantly impair the water use rights of any other border state in the basin of the same river. All water use issues for such rivers are solved at the international level by concluding interstate agreements. For example, in 2013, the Belgorod Region hosted the 1st international scientific and practical conference "Seversky Donets. Ex- 
perience and prospects of joint use and protection of a transboundary water body "and I want to believe that interstate cooperation on the Seversky Donets will continue, as in the Ukraine the annual provision of the population and sectors of the economy with water from this artery until recently amounted to almost 3 million cbm. In addition, joint control in cross-border areas should be continued. River basins are not only operating units of territorial ecology and landscape arrangement, but also objects of agroecological and hydroecological monitoring, which allow to assess the environmental efficiency of geo-planning of territories on basin principles [7, p.58].

High-quality development and realization of the coordinated strategy of use of crossborder water objects requires interstate (international) body, which powers have to be sufficient for permission of conflict situations. It should be a supranational body created by all countries using transboundary resources of water bodies and possess the information necessary for making compromise decisions. Its decisions are obligatory for all participants, procedures of coordination of interests of water users can be only open, the states water users have to be guided by the possible strategy and the principles of objectivity of the made decisions. Coordination of interests of transboundary water users should be carried out taking into account quantitative and qualitative indicators of hydro resources [2, p.306].

A comprehensive solution of environmental and resource problems in the basins of transboundary rivers, implementation of multifaceted investment projects, development of the scientific and technical base and training of personnel should become important factors for the sustainable development of Russia and the Ukraine, and expand their integration cooperation. Implementation from the foregoing is possible because water resources management and conducting water management in our countries, including research, design, construction, operation, rely on common standards and norms. On the one hand, this allows to develop unified approaches to solving comparable problems in the field of water resources management and related sectors of the economy, and on the other, it creates objective conditions for cooperation on the development of new standards and normative and methodological documentation. In addition, the implementation of joint projects on the preparation of general technical conditions and requirements reduces the cost of construction and operation of water facilities, increases their reliability [6, p.86].

The current tense relations between Russia and Ukraine have caused the overlapping of the North Crimean canal, along which the Dnieper water was fed. Previously up to $85 \%$ of the requirements of the Crimea in fresh water fulfilled by the North Crimean Canal. As a result, the inhabitants of the Crimea had to transfer water from the local river BiyukKarasu to the canal and drill new wells. However, this solved the problem only partially. After changing the jurisdiction of the Crimea in 2014, farmers in the Kherson region of Ukraine also suffered in Ukraine, which also stopped receiving fresh water. They also suffered losses from the food blockade of the Crimea, having lost the main market for their products.

In conclusion, it is necessary to say that the transboundary basins of Russia are one of the most urgent problems of the modern water economy of the country. At the solution of political tasks and implementation of the obligations within international cooperation we should not forget about existence of the problems solved on concrete water objects. Scientific researches of ecological character, development of hydrological and water economic simulation models, the forecast of the development of the situation taking into account the planned activities of both own and other countries in terms of regulation and territorial redistribution of water resources should be provided with budgetary financing. Otherwise, if we establish the situation, rather than predict them, the losses in all spheres will be very large.

Лumepamypa 
1. Григорьев Е. Региональные и трансграничные проблемы использования и охраны водных ресурсов // Российский экономический журнал. 2007. № 11-12.

2. Данилов-Данильян В., Хранович И. Трансграничные водные проблемы и подход к их решению. 1. Формирование соглашений // Водные ресурсы. 2013. Т. 40. № 3.

3. Дёмин А.П., Шаталова К.Ю. Принципы и практика распределения водных ресурсов трансграничных рек России // Географрия и природные ресурсы. 2015. № 1.

4. Назаров В.П. О некоторых международных проблемах водопользования в мире и угрозах национальной безопасности России // Право и безопасность. 2010. №2(35).

5. Сотрудничество по трансграничным водам: тенденции в новых независимых государствах. Нью-Йорк, Женева, 2006.

6. Ясинский В.А., Мироненков А.П., Сарсембеков Т.Т. Совершенствование управления водными ресурсами - приоритетная задача стратегии экономического развития СНГ // Право и инвестиции. 2013. № 3-4.

7. Fedor N. Lisetsky, Jeanne A. Buryak, Olesya I. Grigoreva, Olga A. Marinina, Larisa V. Martsinevskaya. Implementation of the Basin-Administrative and Ecoregional Approaches to Environmentally Oriented Arrangement Inter-settlement Areas of the Belgorod Region // Biogeosystem Technique. 2015. Vol. 3.

\section{References}

1. Grigoriev E. Regional and transboundary problems of water resources use and protection // Russian Economic Journal. 2007. No. 11-12.

2. Danilov-Danilyan V., Khranovich I. Transboundary water problems and the approach to their solution. 1. Formation of agreements // Water resources. 2013.Vol. 40. No. 3.

3. Demin A.P., ShatalovaK.Yu. Principles and practice of distribution of water resources of transboundary rivers of Russia // Geography and natural resources. 2015. No. 1.

4. Nazarov V.P. On Some international problems of water use in the world and threats to Russia's national security // Law and Security. 2010.No2 (35).

5. Cooperation on transboundary waters: Trends in the newly independent states. New York, Geneva, 2006.

6. Yasinsky V.A., Mironenkov A.P., Sarsembekov T.T. Perfection of water resources management is a priority task of the strategy of the CIS economic development // Law and Investments. 2013. No. 3-4.

7. Fedor N. Lisetsky, Jeanne A. Buryak, Olesya I. Grigoreva, Olga A. Marinina, Larisa V. Martsinevskaya. Implementation of the basin-administrative and ecoregional approaches to environmentally oriented arrangement inter-settlement areas of the Belgorod region// Biogeosystem Technique. 2015. Vol. 3. 